\title{
Tables and figures
}

\section{Tables}

2.1 The COVID-19 crisis: Indonesia and neighbours, October $2020 \quad 7$

4.1 Fiscal position, 2018-2020 48

4.2 Capital flow in Indonesia's financial market (stocks, government bonds and central bank certificates) (rupiah trillion) 50

4.3 Burden-sharing scheme to finance Indonesia's economic recovery 56

$\begin{array}{lll}4.4 & \text { Fiscal policy package, } 2020 & 61\end{array}$

$\begin{array}{lll}4.5 & \text { Social protection expansion } & 64\end{array}$

5.1 Economic growth and central government revenue, AFC and GFC 79

5.2 Government revenue and intergovernmental transfers, $\begin{array}{ll}\text { global financial crisis (rupiah trillion) } & 81\end{array}$

5.3 Explaining district spending per capita, 2010-2018 82

5.4 Explaining changes in service access, 2010-2018 85

5.5 COVID-19 effects, $2020 \quad 86$

5.6 Impact of COVID-19 on household service access, annual change 86

5.7 Impact of COVID-19 on annual household service access, Java and $\begin{array}{ll}\text { off Java } & 87\end{array}$

5.8 Share of own-source revenues in total budgets 89

6.1 GDP growth by industry and the potential impact on urban and informal jobs, Indonesia, 2017-2020 103

$\begin{array}{lll}7.1 & \text { Indonesia's import reliance, } 2018 & 126\end{array}$

7.2 Indonesian non-tariff measures on agro-food products 126

$\begin{array}{ll}7.3 \text { Import regulations on food: Garlic and onion } & 128\end{array}$

$\begin{array}{ll}8.1 \text { Government social assistance programs } & 139\end{array}$ 


\section{Tables (continued)}

10.A1 Correlation between COVID-19 total cases and total tests, using log function

10.A2 Correlation between COVID-19 total deaths and total tests, using $\log$ function

10.A3 Descriptive summary of variables used in this chapter

\section{Figures}

3.1 Flighty foreign equity and bond holdings, January 2010 September 2020 (rolling 3-month basis, rupiah trillion)

3.2 Portfolio inflows by main components, December 2010 June 2020 (rolling 4 quarters, US\$ billion)

3.3 Tradeable government rupiah debt securities (rupiah trillion)

3.4 International reserves and the rupiah during recent outflow episodes

3.5 Real effective exchange rate and bond yields

3.6 Recent portfolio inflows by main components, March 2019 June 2020 (quarterly, US\$ billion)

3.7 Real exchange rate movements and foreign exchange intervention $\quad 38$

3.8 'Basket, band and crawl' illustration 41

3.9 Financial depth across emerging Asia (\% of GDP) 42

4.1 Yield and external vulnerabilities, 2014-2019 52

4.2 Indonesia's debt-to-GDP ratio compared to other countries (\%) 53

4.3 Debt-to-GDP ratio, debt interest payment and fiscal deficit 54

4.4 Global economic growth predictions, 2020-2021 56

4.5 Stimulus amid the COVID-19 pandemic 57

4.6 GDP growth: Demand side (\%, year on year) 60

4.7 GDP growth: Production side (\%, year on year) 60

4.8 Formal and informal workers by sector, 201966

4.9 Distribution of subsidy and social assistance beneficiaries by decile (\%) 69

4.10 Indonesia's tax ratio, 2015-2019 (\% of GDP) 69

5.1 Cumulative confirmed COVID-19 cases by district, 6 October $2020 \quad 75$

5.2 Cumulative confirmed COVID-19 cases per million population by province, 8 October $2020 \quad 76$

5.3 Impact of COVID-19: Conceptual framework 78

6.1 Unemployment and underemployment in Indonesia, 2004-2020 (\%) 99

6.2 Projections of employment growth in selected ASEAN countries, May 2020 (\% change) 
6.3 Characteristics of workers in COVID-sensitive industries, $2019 \quad 105$

7.1 FAO Food Price Index, January 1990 to September 2020 $(2014-2016=100)$

7.2 Rice commodity prices, Thailand and Vietnam, January 2019 to September 2020 (US\$/tonne)

7.3 Rice production in Indonesia and in the world, 1961-2019 (milled, million tonnes)

7.4 Rice-producing regions and COVID-19

7.5 Food prices in the lead-up to the pandemic outbreak, January 2018 to August 2020 (January $2018=100$ )

7.6 Consumption expenditure, March 2018 to June 2020 (March $2018=100)$

7.7 Farmers' terms of trade, January 2019 to September 2020 $(2018=100)$

7.8 Domestic and world price of rice, 1995 to March 2020 (rupiah/kg)

7.9 Domestic and world price of beef, 2011-2019 (rupiah/kg)

8.1 Beneficiaries of social welfare by program (\%)

8.2 Coverage of social assistance program by decile (\%)

8.3 Comparison of proxy means testing and community-targeting methods for determining poverty, by decile

9.1 Changes in the burden of disease, 1990-2019 153

9.2 Geographical variations in hypertension (\%)

9.3 Socioeconomic correlates of hypertension and underdiagnoses of hypertension

9.4 NCD prevalence in 2018 and confirmed COVID-19 deaths, 31 August 2020

9.5 Disruption of health services, October 2019 to May 2020

10.1 Regional distribution of confirmed cases of COVID-19, mid-October 2020

10.2 COVID-19 tests per thousand people in several countries, mid-August 2020

10.3 Estimated COVID-19 cases and tests per thousand people 175

10.4 Estimated COVID-19 deaths and tests per thousand people 177

10.5 Possible mechanisms of COVID-19 impacts to human capital development 